\title{
PENERAPAN MODEL PEMBELAJARAN PROBLEM BASED LEARNING TERHADAP HASIL BELAJAR BIOLOGI SISWA PADA MATERI POKOK SISTEM PENCERNAAN PADA MANUSIA DI SMKS-PP PUTRA JAYA STABAT
}

\author{
KHAIRINA AFNI \\ STKIP Budidaya Binjai \\ khairinaafni89@gmail.com
}

\begin{abstract}
Penelitian ini bertujuan untuk mengetahui penerapan model pembelajaran Problem Based Learning terhadap hasil belajar biologi siswa pada materi pokok sistem pencernaan pada manusia di SMKS-PP Putra Jaya Stabat. Penelitian ini merupakan penelitian eksperimen yang diadakan selama bualan Agustus - Nopember 2019. Populasi dalam penelitian ini adalah seluruh siswa kelas XI Pertanian SMKS-PP T.A 2019/2020 yang terdiri dari 3 kelas (115 siswa) sedangkan sampel dalam penelitian ini diambil secara random yang terdiri dari dua kelas (76 siswa) yaitu kelas XI Nak-A sebagai kelas kontrol dan XI Nak -B sebagai kelas eksperimen. Metode yang digunakan dalam penelitian ini adalah metode eksperimen dengan desain eksperimen pretest-posttest control group desaign. Alat pengumpul data pada penelitian ini berupa tes pilihan berganda sebanyak 25 soal setelah tes diuji terlebih dahulu validitas, reliabilitas, daya beda soal dan tingkat kesukaran soal. Hasil penelitan menunjukkan bahwa data nilai siswa baik pre tes maupun post tes dari kedua sampel yang diuji dengan uji normalitas Liliefors berdistribusi normal sedangkan untuk uji homogenitas dengan uji $\mathrm{F}$, data pre tes dan post tes dari kedua sampel tersebut memiliki varians yang sama (homogen). Dari pengolahan data diperoleh nilai rata-rata kelas eksperimen pada hasil pretest $=53,5$ dan pada hasil postest $=75$ Sedangkan nilai rata-rata kelas kontrol pada hasil pretest $=40,2$ dan pada hasil posttest $=68$. Dari nilai rata-rata tersebut terlihat bahwa rata-rata hasil belajar kelas eksperimen yang diajarkan dengan pembelajaran Problem Based Learning lebih baik. Hasil perhitungan uji normalitas dan uji homogeniras menunjukkan bahwa data berdistribusi normal dan juga homogen. Berdasarkan hasil uji hipotesis pada data postest dengan menggunakan uji $t$ diperoleh nilai $t_{\text {hit }}>t_{\text {tab }}(2,23>2,05)$ sehingga dapat disimpulkan bahwa terdapat peningkatan model pembelajaran Problem Based Learning terhadap hasil belajar biologi siswa pada materi pokok sistem pencernaan pada manusia di SMKS-PP Putra Jaya Stabat.
\end{abstract}

Kata Kunci $\quad$ : Problem Based Learning, Hasil Belajar, Siswa

\section{PENDAHULUAN}

Dunia pendidikan sampai saat ini masih didominasi oleh pandangan bahwa pengetahuan adalah seperangkat fakta-fakta yang harus dihafal. Guru berperan sebagai sumber utama pengetahuan yang melakukan perencanaan, pelaksanaan, penilaian, serta hasil belajar, sedangkan siswa hanya berperan sebagai pengikut kegiatan belajar yang dilakukan guru. Dengan demikian metode konvensional menjadi pilihan utama dalam strategi belajar mengajar yang berlangsung.

Salah satu masalah yang dihadapi dunia pendidikan adalah masalah lemahnya proses pembelajaran. Dalam proses 
pembelajaran, siswa kurang didorong untuk mengembangkan kemampuan berfikir. Proses pembelajaran di kelas diarahkan kepada kemampuan seseorang untuk menghafal informasi. Otak seseorang dipaksa untuk mengingat dan menimbun berbagai informasi yang diingatnya itu untuk dihubungkan dalam kehidupan seharihari. Akibatnya ketika seorang siswa lulus dari sekolah, mereka pintar teoritis tetapi mereka miskin aplikasi. Dengan kata lain, proses pendidikan kita tidak diarahkan membentuk manusia cerdas, memiliki kemampuan memecahkan masalah hidup, serta tidak diarahkan untuk membentuk manusia yang kreatif dan inovatif (Sudarman, 2005).

Terkait dengan permasalahan yang timbul dalam dunia pendidikan (Direktorat Tenaga Kependidikan, 2008) menyatakan bahwa ada empat masalah pokok yang sangat penting yang dapat dijadikan pedoman dalam pelaksanaan kegiatan belajar mengajar sesuai dengan yang diharapkan yaitu: (1) spesifikasi dan kualifikasi perubahan tingkah laku yang diinginkan sebagai hasil belajar mengajar yang dilakukan; (2) memilih cara pendekatan belajar mengajar yang dianggap paling tepat dan efektif untuk mencapai sasaran; (3) memilih dan menetapkan prosedur, metode, dan teknik belajar mengajar yang dianggap paling tepat dan efektif; (4) menetapkan norma-norma atau kriteria keberhasilan sehingga guru mempunyai pegangan yang dapat dijadikan ukuran untuk menilai sampai sejauh mana keberhasilan tugas-tugas yang dilakukan. Kenyataan menunjukkan, bahwa pembelajaran di sekolah khususnya pembelajaran biologi hingga kini masih banyak yang berpusat pada guru (teacher centered). Guru lebih mengutamakan metode konvensional dan cenderung mendominasi sehingga siswa cenderung pasif, kurang termotivasi, dan tidak terjadi interaksi dalam pembelajaran. Perlu disadari, bahwa siswa bukanlah penonton olahraga. Siswa tidak banyak belajar hanya dengan duduk di kelas mendengarkan guru, menghafal, dan menyelesaikan tugas.

Berdasarkan hasil observasi dengan guru biologi SMKS-PP Putra Jaya Stabat diperolah bahwa pembelajaran biologi tidak berpatokan pada pembelajaran yang berorientasi pada hakikat IPA yang meliputi produk, proses, dan sikap ilmiah melalui keterampilan proses sehingga ditemukan bahwa selama proses pembelajaran biologi berlangsung siswa cenderung pasif. Guru sudah berupaya membuat siswa aktif dalam proses pengajarannya, seperti mengkondisikan siswa bekerja dalam kelompok dalam menyelesaikan tugas, namun upaya ini belum dapat meningkatkan aktivitas siswa. Siswa tidak memperhatikan guru menerangkan pelajaran. Siswa tampak jenuh, melamun, tidak mencatat materi pelajaran, tidak konsentrasi, dan mengantuk. Dan di akhir pelajaran, siswa tidak dapat menjawab pertanyaan guru tentang pelajaran yang baru saja disampaikan. Ketika diminta untuk bertanya tentang halhal yang tidak dimengerti, siswa sering kali hanya diam. Dalam kerja kelompok, ada kecenderungan siswa yang pintar saja yang bekerja menyelesaikan tugas. Di samping itu, siswa hanya berorientasi pada penyelesaian tugas saja dan tidak berupaya untuk memahami pelajaran. Keadaan ini menunjukkan bahwa aktivitas belajar siswa masih rendah dalam mengikuti kegiatan 


\section{Jurnal Serunai Ilmu Pendidikan \\ Vol.6, No.1, Juni 2020 \\ e-ISSN $2621-2676$ \\ p-ISSN 2528 - 0775}

belajar mengajar. Selain itu, masalah yang sering dihadapi siswa adalah rendahnya kemampuan siswa dalam memahami materi pelajaran biologi, ini disebabkan karena siswa tidak memiliki ketrampilan belajar biologi.

Salah satu metode yang banyak diadopsi untuk menunjang pendekatan pembelajaran leaner centered dan yang memberdayakan pembelajar adalah metode Problem Based Learning (Amir, 2010). Pembelajaran berbasis masalah (problem based learning), merupakan salah satu model pembelajaran inovatif yang dapat memberikan kondisi belajar aktif kepada siswa. Pembelajaran berbasis masalah adalah suatu model pembelajaran yang melibatkan siswa untuk memecahkan suatu masalah melalui tahap-tahap metode ilmiah sehingga siswa dapat mempelajari pengetahuan yang berhubungan dengan masalah tersebut dan sekaligus memiliki ketrampilan untuk memecahkan masalah (Hajriana, 2010).

Problem based learning merupakan metode instruksional yang menantang siswa agar "belajar untuk belajar" bekerja sama dalam kelompok untuk mencari solusi bagi masalah yang nyata. Masalah ini digunakan untuk mengaitkan rasa keingintahuan serta kemampuan analisis siswa dan mengambil inisiatif atas materi pelajaran. Model ini memungkinkan siswa untuk belajar pengetahuan baru dengan menghadapi masalah yang harus dipecahkan yang diberikan ke dirinya. Melalui pembelajaran berbasis masalah, beberapa sikap siswa dalam kaitannya dengan bidang-bidang seperti kerja kelompok pemecahan masalah, berpikir, komunikasi, perolehan informasi dan berbagi informasi dengan orang lain akan berpengaruh secara positif (Akınoglu, 2007). Salah satu metode yang banyak diadopsi untuk menunjang pendekatan pembelajaran leaner centered dan yang memberdayakan pembelajar adalah metode Problem Based Learning (Amir, 2010). Pembelajaran berbasis masalah (problem based learning), merupakan salah satu model pembelajaran inovatif yang dapat memberikan kondisi belajar aktif kepada siswa. Pembelajaran berbasis masalah adalah suatu model pembelajaran yang melibatkan siswa untuk memecahkan suatu masalah melalui tahap-tahap metode ilmiah sehingga siswa dapat mempelajari pengetahuan yang berhubungan dengan masalah tersebut dan sekaligus memiliki ketrampilan untuk memecahkan masalah (Hajriana, 2010).

Problem based learning merupakan metode instruksional yang menantang siswa agar "belajar untuk belajar" bekerja sama dalam kelompok untuk mencari solusi bagi masalah yang nyata. Masalah ini digunakan untuk mengaitkan rasa keingintahuan serta kemampuan analisis siswa dan mengambil inisiatif atas materi pelajaran. Model ini memungkinkan siswa untuk belajar pengetahuan baru dengan menghadapi masalah yang harus dipecahkan yang diberikan ke dirinya. Melalui pembelajaran berbasis masalah, beberapa sikap siswa dalam kaitannya dengan bidang-bidang seperti kerja kelompok pemecahan masalah, berpikir, komunikasi, perolehan informasi dan berbagi informasi dengan orang lain akan berpengaruh secara positif (Akınoglu, 2007). 


\section{TUJUAN PENELITIAN}

Adapun tujuan dari penelitina ini adalah untuk mengetahui penerapan model pembelajaran Problem Based Learning terhadap hasil belajar biologi siswa pada materi pokok sistem pencernaan pada manusia di SMKS-PP Putra Jaya Stabat

\section{METODE PENELITIAN}

Jenis penelitian ini adalah penelitian eksperimen dengan teknik pengambilan data sampel total, dimana jumlah populasi sama dengan sampel yaitu siswa kelas XI SMKSPP Putra Jaya Stabat yang terdiri dari 2 kelas yang masing-masing berjumlah 38 orang, sehingga total seluruh sampel adalah 76 orang. Metode yang digunakan dalam penelitian ini adalah metode eksperimen dengan desain eksperimen pretest-posttest control group desaign. Sehingga penelitian dilakukan dengan tahapan sebagai berikut : Tahap Persiapan

meliputi (a) Melakukan observasi; (b) Menetapkan jadwal penelitian; (c) Menyusun rencana pelaksanaan pembeljaran (RPP); (d) Menyiapkan media; (e) Menyiapkan soal tes; (f) Uji tes awal. Tahap pelaksanaan penelitian meliputi (a) Pengambilan sampel dari populasi; (b) Membagi sampel menjadi kelas kontrol dan kelas eksperimen, kemudian kelas kontrol dan kelas eksperimen dilakukan pre test untuk mendapatkn data awal; (c) Siswa diberi pengajaran tentang Materi Struktur dan Fungsi Sel, di kelas eksperimen diterapkan pembelajaran dengan menggunakan media audiovisual sedangkan untuk kelas kontrol diterapkan pembelajaran konvensional tanpa media audiovisual; (d) Siswa diberi post test untuk mengukur hasil belajar siswa; (e) Setelah itu dilakukan analisa data.

\section{PEMBAHASAN DAN HASIL PENELITIAN}

Dari hasil pretes diketahui nilai ratarata siswa pada nilai rata-rata kelas eksperimen pada hasil pretest $=53,5$ dan pada hasil postest $=75$ dengan simpangan baku (SD) sebesar 7,15 Sedangkan nilai rata-rata kelas kontrol pada hasil pretest $=$ 40,2 dan pada hasil posttest $=68$ dengan simpangan baku (SD) sebesar 7,02. Dari hasil tersebut dapat disimpulkan bahwa ada perbedaan hasil belajar siswa pada kedua kelas setelah diberikan perlakuan dengan pembelajaran menggunakan model dan tidak menggunakan model sama sekali. Sementara pada uji normalitas dilakukan dengan menggunakan uji Liliefors dengan taraf signifikansi $\alpha=0,05$.

Pengujian hipotesis dilakukan dengan menggunakan uji beda (uji-t). Uji-t dilakukan dengan membandingkan nilai rata-rata rata-rata postest dari kedua kelompok penelitian. Dari hasil perbandingan harga $t_{\text {hitung }}$ dengan $t_{\text {tabel }}$ diketahui bahwa $t_{\text {hitung }}>t_{\text {tabel }}(2,23>2,05)$ Dengan melihat hasil tersebut dapat disimpulkan bahwa dalam penelitian ini $\mathrm{H}_{\mathrm{a}}$ diterima sekaligus menolak $\mathrm{H}_{0}$ yang berarti terdapat peningkatan model pembelajaran Problem Based Learning terhadap hasil belajar biologi siswa pada materi pokok sistem pencernaan pada manusia di SMKSPP Putra Jaya Stabat. Dari hasil pengujian hipotesis tersebut juga dapat disimpulkan bahwa pembelajaran yang dilakukan dengan menggunakan model pembelajaran Problem Based Learning lebih efektif untuk 


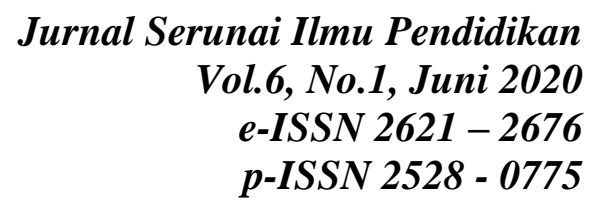

meningkatkan hasil belajar siswa pada materi pokok sistem pencernaan dibandingkan dengan pembelajaran tanpoa menggunakan model pembelajaran.

Berdasarkan uraian diatas dapat dilihat bahwa hasil belajarnya yaitu berupa kemampuan yang diperoleh setelah mendapatkan kegiatan belajar yang mengakibatkan perubahan dalam diri individu sebagai hasil dari aktivitas dalam belajar. Program pengajaran dapat dipandang sebagai usaha mengubah tingkah laku siswa dengan mengubah bahan pengajaran. Tingkah laku yang diterapkan itu terjadi setelah siswa mempelajari pelajaran tersebut. Hasil belajarnya dapat berupa pengetahuan, keterampilan, dan perubahan sikap. Hasil belajar siswa sangat erat kaitanya dengan tujuan intruksional yang sudah direncanakan guru sebelumnya. Hal ini juga dipengaruhi oleh kemampuan guru sebagai perancang belajar mengajar. Tujuan intruksional dapat dikelompokkan dalam tiga kategori yaitu kognitif, afektif, dan psikomotorik. Dengan demikian tujuan belajar adalah terjadinya perubahan tingkah laku individu yang belajar dimana perubahan perilaku tersebut merupakan perubahan yang bersifat positif. Hal ini sesusai dengan harapan peneliti bahwa hasil belajar dengan menggunakan model pembelajaran Problem Based Learning hasilnya lebih baik di bandingkan dengan pengajaran menggunakan model konvensional.

Hasil belajar bergantung pada apa yang dipelajari dan faktor-faktor yang mempengaruhi proses belajar. Karena faktor yang mempengaruhi proses belajar tidak pernah sama, sehingga hasil belajar juga dapat terjadi perbedaan. Seseorang dapat dikatakan memiliki kemampuan prestasi belajar dalam bidang studi biologi yaitu apabila tujuan yang direncanakan dalam pengajaran tersebut tidak secara kognitif, afektif, dan psikomotorik seperti yang terlihat dalam diri siswa yang mengikuti interaksi belajar mengajar. Dalam kamus besar bahasa Indonesia (2001) dikemukakan bahwa : "kemampuan adalah kesanggupan". Kecakapan seseorang dalam melakukan sesuatu aktifitas. Setiap orang memiliki kemampuan yang berbeda-beda baik dalam menerima, mengingat maupun menggunakan sesuatu yang diterimanya. Hal ini disebabkan bahwa setiap orang memiliki cara yang berbeda dalam hal menyusun. segala sesuatu yang diamati, dilihat, diingat maupun dipikirkannya. Siswa juga dapat berbeda dalam cara menerima, mengorganisasikan dalam cara pendekatan terhadap situasi belajar dan menghubungkan pengalamanpengalamannya tentang pelajaran serta cara mereka merespon terhadap metode pengajaran (Afni, Khairina. 2019)

Rendahnya prestasi dalam bidang Ilmu Pengetahuan Alam (IPA) dalm hal ini pelajara Biologi khususnya di sekolah menjadi masalah yang harus mendapat banyak perhatian dan pemecahan. Banyak faktor yang menyebabkan prestasi belajar rendah, diantaranya dapat berasal dari dalam diri siswa (faktor internal) maupun dari luar diri siswa (faktor eksternal). Salah satu faktor yang berasal dari dalam diri siswa adalah aktivitas siswa. Salah satu faktor eksternal bersumber dari guru adalah penggunaan model pembelajaran yang kurang bervariasi dalam proses pembelajaran (Sitepu, DRB, 2019). 


\section{KESIMPULAN}

Kesimpulan dari penelitian ini adalah : terdapat peningkatan model pembelajaran Problem Based Learning terhadap hasil belajar biologi siswa pada materi pokok sistem pencernaan pada manusia di SMKS-PP Putra Jaya Stabat hal ini dapat dilihat dari perbedan rata-rata nilai pretest dan postest siswa, sehingga penerapan model pembelajaran Problem Based Learning terhadap hasil belajar biologi siswa pada materi pokok sistem pencernaan pada manusia di SMKS-PP Putra Jaya Stabat dapat meningkat lebih baik.

\section{DAFTAR PUSTAKA}

Afni, Khairina. 2019. Upaya Meningkatkan Kemampuan Pemecahan Masalah Menggunakan Pendekatan

Pembelajaran Saintifik Pada Materi Pokok Sistem Pencernaan Pada Manusia Di Kelas VIII SMP Putra Jaya Stabat Tahun Pelajaran 2018/2019. Jurnal Serunai Ilmu Pendidikan. Vol, 5 No 1. Hal 1-10.

Akınoglu, Orhan and Ruhan Ozkardes Tandogan. 2007. The Effects of
Problem. Based Active Learning in Science Education on Students' Academic.

Amir. 2010. Inovasi Pendidikan melalui Problem Based Learning. Jakarta: Prenada Media Group

Hajriana. 2010. Problem Based Learning (PembelajaranBerbasis Masalah). [online] http://hajrianawarnadunia .blogspot.com/2010/04/ problembasedlearning-pembelajaran.

Sitepu, DRB. 2019. Penerapan Model Biologi Materi Xi Ipa Model Quantum Teaching Pada Pembelajan Pembelajaran Materi Pokok Sistem Ekskresi Manusia Di Kelas XI IPA SMA Swasta Esa Prakarsa Manusia Di Kelas. Proseding seminar Nasional Multi Disiplin Ilmu Universitas Asahan. Hal: 1-9.

$\begin{array}{ccr}\text { Sudarman. 2007. } & \text { "Problem } & \text { Based } \\ \text { Learning: } & \text { Suatu } & \text { Model } \\ \text { Pembelajaran } & & \text { untuk } \\ \text { Mengembangkan dan Meningkatkan }\end{array}$ Kemampuan Memecahkan Masalah". Jurnal Pendidikan Inovatif Vol. 2 No. 2. Hal: 68-73. 